\title{
Solid Waste Characterization in Ethiope East Local Government Area Of Delta State, Abraka, Nigeria
}

\section{OBIAJULU PERETOMODE}

\author{
Department of Science Laboratory Technology, Delta State University, Abraka, P.M.B 1. Nigeria. \\ Email: obipere@gmail.com; Tel: +2347067625991,+2349081359717
}

\begin{abstract}
On-site waste characterization was carried out on four dumpsites in Abraka municipality with standard methods used. Results obtained show that the mean composition of organic waste was significantly higher in station 1 $(38.15 \pm 2.03)$ than other stations, while paper waste $(18.97 \pm 0.43)$, glass waste $(1.84 \pm 0.18)$, metal waste $(3.03 \pm 0.12)$ and other miscellaneous wastes were significantly higher in station 2 than other stations. Plastic waste was significantly higher in station 4 (7.85 \pm 0.29$)$ than other stations. Wastes disposed carelessly spread to the road and to surrounding water bodies. Community participation in waste disposal can be a catalyst in community development work, because it gives residents a feeling of self-esteem, generates income through recycling and reduce waste material transported for disposal.
\end{abstract}

\section{DOI: https://dx.doi.org/10.4314/jasem.v22i12.6}

Copyright: Copyright (C 2018 Obiajulu. This is an open access article distributed under the Creative Commons Attribution License (CCL), which permits unrestricted use, distribution, and reproduction in any medium, provided the original work is properly cited.

Dates: Received: 30 March 2018; Revised: 19 Novmber 2018; Accepted 22 December 2018

Keywords: Solid waste; Municipal; Characterization; Composition

Since the day God created man, the earth has known no peace (Seo et al, 2004). a cordial relationship Initially existed between man and his environment, the air he breathed was fresh, his food was uninfected, his water potable and his land fertile. Man's relationship with his environment was that of mutual respect.

However, since man misconstrued God's injunction of "have dominion over the fish of the sea" and his quest for technological advancement, man breached the tacit agreement of trust reached with his environment. Man has continued to lord over the environment to his own detriment.

The deterioration of the environment has resulted in an increase in diseases; reduction of average life span and growth in infant mortality rates. (Seo et al, 2004). Solid waste disposal and management are both an urban and rural problem.

Every person is a potential generator of waste and thus a contributor to these problems. To generate waste is one thing, the type of waste generated is another and yet the way the generated waste is managed or disposed of is quite a different issue. Usually, the rate at which solid waste is generated is far higher than the capacity to responsibly manage this waste as waste is generated by, and from different sectors; domestic, commercial, industry and other sources and instances, the waste management responsibility has been left to the government or administrative authorities (Zhenshan et al, 2009).

Rapid economic growth, fast growing populations and a rise in community living standards have accelerated the generational rate of solid waste causing its management to be a major challenge. In urban cities of developing countries such as Abraka in Delta state of Nigeria, solid waste management is a highly neglected area (Ahmed and Ali, 2004).

The awareness that improper handling of solid waste leads to contamination of water, soil and atmosphere and is a major impact on public health has caused developing nations to address this issue with increasing urgency (Batool, 2009 and Sharholy et al, 2008). In particular, the collection of solid waste has been identified as a major problem since in many areas, local authorities are either unable or unwilling to provide waste collection services to all residents in their area of jurisdiction.

The importance of solid waste characterization cannot be over emphasized as waste characterization studies helps government planners, haulers, and recyclers estimate the amount of certain solid waste materials in their waste stream and for its management. The aim of this study is to characterize solid waste disposed in selected dump sites in ethiope east local government area of Delta state, Abraka, Nigeria. 


\section{MATERIALS AND METHODS}

Description of study station: This study was conducted in Abraka, Ethiope East Local Government Area of Delta State, Nigeria (lat.5' $51 \mathrm{~N}$ and 5' $54 \mathrm{~N}$ and long. 6' $08 \mathrm{E}$ and 6' $12 \mathrm{E}$ ). This settlement is situated at the eastern bank of River Ethiope, and covers a total land area of about $21.2 \mathrm{~km}^{2}$. The topography is a low plain and drained by River Ethiope (Delta State Government, 2007).

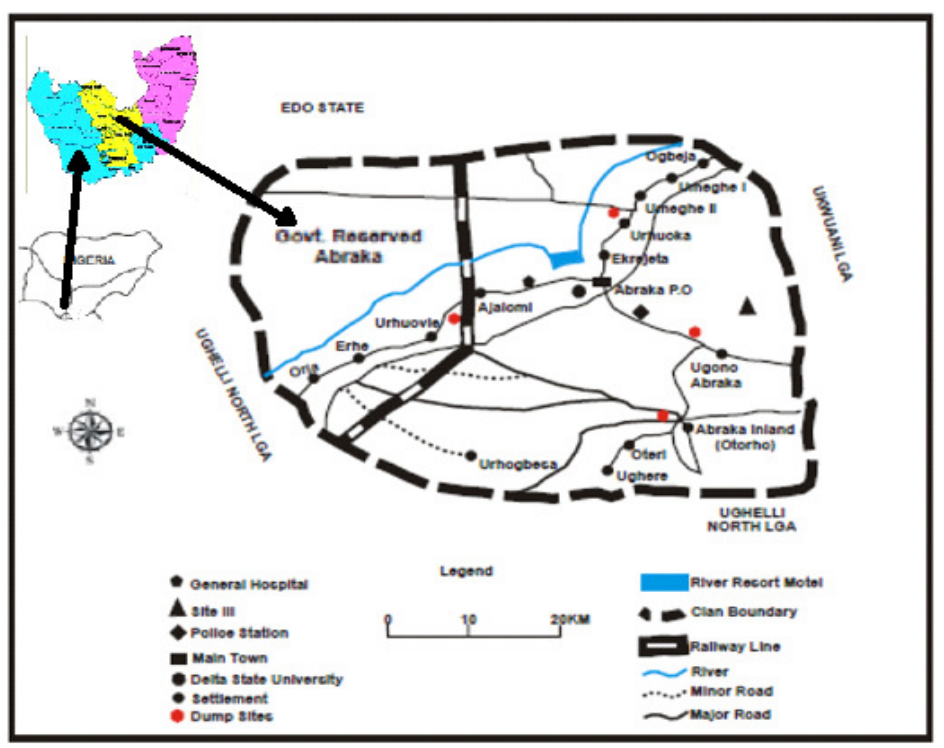

Fig 1: Map of Abraka Town showing Study Sites(Delta state government, 2007).

Description of Study Areas: Abraka has only one government approved dump site and several other illegal dump sites. For the purpose of this study, four dump sites were used; one government approved dump site and three illegal dump sites.

\begin{tabular}{lllllll}
\multicolumn{7}{c}{ Table 1: Station 1 $(\%)}$. \\
\hline $\begin{array}{lllllll}\text { Station } \\
1\end{array}$ & Organics & paper & plastic & glass & metals & others \\
\hline Aug & 38.63 & 8.63 & 1.05 & 0.14 & 1.26 & 0.30 \\
Sept & 30.56 & 17.49 & 0.93 & 0.06 & 0.81 & 0.15 \\
Oct & 47.74 & 0.58 & 0.37 & 0.10 & 1.02 & 0.18 \\
Nov & 45.13 & 1.75 & 1.40 & 0.08 & 1.46 & 0.18 \\
Dec & 34.42 & 13.47 & 0.90 & 0.10 & 0.84 & 0.26 \\
Jan & 34.00 & 13.68 & 0.99 & 0.07 & 1.12 & 0.14 \\
Feb & 37.40 & 10.20 & 1.03 & 0.07 & 1.14 & 0.16 \\
Mar & 37.30 & 10.28 & 1.05 & 0.06 & 1.15 & 0.16 \\
\hline
\end{tabular}

Dumpsite 1: This is a government approved dump site, located along Abraka-Benin express road in Urhuoka community. Sand was collected from this site for construction purpose and it became a burrowed pit and was approved by the government to help reclaim the land. This dump site is off the road and communities close to this dump site are Urhoka, Ekrejeta, Umeghe II and the University. These communities dispose their wastes on this site and all kinds of wastes are found on this site. The quantity of waste on this site is very high due to the socio-cultural background and high economic activities. Waste materials that can be found here are paper, cans, bottles, metals, plastics , decomposable and other wastes as shown in the table 1 .

Station 2: This is an illegal dump site that has been in existence for five years. It is located along AbrakaUgono road, very close to Ugono River in Ugono community. Communities close to this dump site are Abraka P.O and Ugono. Waste disposed on this site overflows to the river bank, waste materials also include paper, plastic, cans metals and decomposable waste as shown in the table 2 .

Table 2: Station 2(\%).

\begin{tabular}{lllllll}
\hline Station 2 & Organics & paper & plastic & glass & metals & others \\
\hline Aug & 14.45 & 18.86 & 8.71 & 0.90 & 2.82 & 4.25 \\
Sept & 13.78 & 20.88 & 8.39 & 2.38 & 2.95 & 1.61 \\
Oct & 14.00 & 16.62 & 9.18 & 2.62 & 3.18 & 4.41 \\
Nov & 17.19 & 18.33 & 7.53 & 1.71 & 2.75 & 2.49 \\
Dec & 14.80 & 19.39 & 7.14 & 1.53 & 2.55 & 4.59 \\
Jan & 18.89 & 19.74 & 0.92 & 1.89 & 3.61 & 4.95 \\
Feb & 18.22 & 18.99 & 3.02 & 1.87 & 3.18 & 4.73 \\
Mar & 18.91 & 18.97 & 1.99 & 1.85 & 3.24 & 5.04 \\
\hline
\end{tabular}

Station 3: This is an illegal dump site that has been in existence for three years and it is located within Abraka inland in Otorho Community. Communities close to this dump site are Otorho and Oteri, these are rural communities. This dump site has quantities of paper, plastic, farm, food, garden and decomposable wastes as shown in the table 3 . 
Station 4: This dump site is located along the railway track in Urhuovie community. Communities close to this dump site are Ajalomi, Urhuovie and Erhe, these are rural communities. Waste materials found in this dump site are paper, plastic, farm and decomposable wastes as shown in in the table 4 .

Table 3: Station 3(\%)

\begin{tabular}{lllllll}
\multicolumn{7}{c}{ Table 3: Station 3(\%) } \\
$\begin{array}{lllllll}\text { Station } \\
3\end{array}$ & Organics & paper & plastic & glass & metals & others \\
\hline Aug & 36.93 & 6.38 & 1.93 & 0.97 & 1.09 & 2.70 \\
Sept & 36.90 & 7.17 & 2.01 & 0.96 & 1.16 & 1.79 \\
Oct & 37.01 & 6.97 & 1.81 & 0.88 & 1.17 & 2.15 \\
Nov & 37.19 & 5.86 & 2.30 & 0.98 & 1.01 & 2.66 \\
Dec & 36.92 & 6.75 & 1.97 & 0.96 & 1.13 & 2.28 \\
Jan & 35.35 & 8.41 & 1.55 & 0.81 & 1.34 & 2.55 \\
Feb & 36.32 & 7.24 & 1.88 & 0.90 & 1.19 & 2.47 \\
Mar & 36.23 & 7.33 & 1.87 & 0.89 & 1.20 & 2.48 \\
\hline
\end{tabular}

Table 4: Station 4(\%)

\begin{tabular}{lllllll}
\multicolumn{7}{c}{ Table 4: Station 4(\%) } \\
\hline $\begin{array}{l}\text { Station } \\
4\end{array}$ & Organics & paper & plastic & glass & metals & others \\
\hline Aug & 14.45 & 18.86 & 8.71 & 0.90 & 2.82 & 4.25 \\
Sept & 13.78 & 20.88 & 8.39 & 2.38 & 2.95 & 1.61 \\
Oct & 14.00 & 16.62 & 9.18 & 2.62 & 3.18 & 4.41 \\
Nov & 17.19 & 18.33 & 7.53 & 1.71 & 2.75 & 2.49 \\
Dec & 14.80 & 19.39 & 7.14 & 1.53 & 2.55 & 4.59 \\
Jan & 16.23 & 16.96 & 7.83 & 1.63 & 3.10 & 4.25 \\
Feb & 16.56 & 17.31 & 7.15 & 1.80 & 2.87 & 4.31 \\
Mar & 16.98 & 16.97 & 6.88 & 1.81 & 2.86 & 4.51 \\
\hline
\end{tabular}

Waste characterization: On-site waste characterization was carried out on four (4) dump sites in the study area by collecting fifty kilograms $(50 \mathrm{~kg})$ of waste from each of the dump site. The wastes collected from each of the dump site were weighed and sorted to know the type of waste that is predominant in each dump site. Weighing and sorting were done on each of the dump site once every month for eight (8) months. Waste characterization was carried out on the four dump sites for a period of eight (8) months so as to cover both wet and dry seasons.

Observation as a tool: An observation guide was used in this study. Mongtoem et al, 2014, defined observation as a process of systematically recording verbal and non- verbal behaviour and communication without asking specific questions. This was used in this project as it generated both qualitative and quantitative data. Beside the above point, the method enabled the researcher to separate facts from the interpretation of the facts and observed the facts and made an interpretation at a later time. Observation method is quite essential as one can benefit a great deal in research through observation of occurrences in the field of the study (Mongtoem et al.,2014).

Statistical analysis: Data collected were subjected to statistical tests of significance using the Student t-test, Analysis of Variance (ANOVA) at $\mathrm{p}<0.05$.

\section{RESULTS AND DISCUSSION}

Waste characterization: The results of waste characterization are presented in table 1 . The results show the mean composition of waste in four dump sites in the Abraka area of Delta state. Organic waste: Mean composition of organic waste was significantly higher in station $1(38.15 \pm 2.03)$ than other stations, with the least value reported in station $4(15.50 \pm 0.49)$ as shown in table 5 . In station 2, it was highest in January (18.89\%) and lowest in September (13.78\%).

Paper waste: Mean composition of paper waste was significantly higher in station $2(18.97 \pm 0.43)$ than other stations, with the least value reported in station 3 (7.01 \pm 0.26$)$. In station 2, Mean paper waste composition was highest in September $(20.88 \%)$ and lowest in October (16.62\%); in station 3, it was highest in January $(8.41 \%)$ and lowest in November $(5.86 \%)$; in station 4, it was highest in September $(20.88 \%)$ and lowest in October $(16.62 \%)$.

Plastic waste: Mean composition of plastic waste was significantly higher in station $4(7.85 \pm 0.29)$ than other stations, with the least value reported in station 1 $(0.97 \pm 0.10)$.

Table 5. Waste Characterization of four dumpsites in Abraka area

\begin{tabular}{|c|c|c|c|c|c|}
\hline Materials (Kg) & Station 1 & Station 2 & Station 3 & Station 4 & P-alue \\
\hline & $\begin{array}{l}\text { Mean } \pm \text { SE } \\
\text { (Min-Max) }\end{array}$ & $\begin{array}{l}\text { Mean } \pm \text { SE } \\
\text { (Min-Max) }\end{array}$ & $\begin{array}{l}\text { Mean } \pm \text { SE } \\
\text { (Min-Max) }\end{array}$ & $\begin{array}{l}\text { Mean } \pm \text { SE } \\
\text { (Min-Max) }\end{array}$ & \\
\hline Organics (Kg) & $\begin{array}{l}38.15 \pm 2.03 \\
(30.56-7.74)\end{array}$ & $\begin{array}{l}16.28 \pm 0.79 \\
(13.78-8.91)\end{array}$ & $\begin{array}{l}36.61 \pm 0.22 \\
(35.35-7.19)\end{array}$ & $\begin{array}{l}15.50 \pm 0.49 \\
(13.78-7.19)\end{array}$ & $\mathrm{P}<0.05$ \\
\hline Paper (Kg) & $\begin{array}{l}9.51 \pm 2.06 \\
(0.58-17.49)\end{array}$ & $\begin{array}{l}18.97 \pm 0.43 \\
(16.62-0.88)\end{array}$ & $\begin{array}{l}7.01 \pm 0.26 \\
(5.86-8.41)\end{array}$ & $\begin{array}{l}18.17 \pm 0.52 \\
(16.62-0.88)\end{array}$ & $\mathrm{P}<0.05$ \\
\hline Plastics (Kg) & $\begin{array}{l}0.97 \pm 0.10 \\
(0.37-1.4)\end{array}$ & $\begin{array}{l}5.86 \pm 1.18 \\
(0.92-9.18)\end{array}$ & $\begin{array}{l}1.92 \pm 0.07 \\
(1.55-2.30)\end{array}$ & $\begin{array}{l}7.85 \pm 0.29 \\
(6.88-9.18)\end{array}$ & $\mathrm{P}<0.05$ \\
\hline Glass (Kg) & $\begin{array}{l}0.08 \pm 0.01 \\
(0.06-0.14)\end{array}$ & $\begin{array}{l}1.84 \pm 0.18 \\
(0.9-2.62)\end{array}$ & $\begin{array}{l}0.92 \pm 0.02 \\
(0.81-0.98)\end{array}$ & $\begin{array}{l}1.80 \pm 0.19 \\
(0.90-2.62)\end{array}$ & $\mathrm{P}<0.05$ \\
\hline Metals (Kg) & $\begin{array}{l}1.10 \pm 0.08 \\
(0.81-1.46)\end{array}$ & $\begin{array}{l}3.03 \pm 0.12 \\
(2.55-3.61)\end{array}$ & $\begin{array}{l}1.16 \pm 0.03 \\
(1.01-1.34)\end{array}$ & $\begin{array}{l}2.88 \pm 0.07 \\
(2.55-3.18)\end{array}$ & $\mathrm{P}<0.05$ \\
\hline Others (Kg) & $\begin{array}{l}0.19 \pm 0.02 \\
(0.14-0.3)\end{array}$ & $\begin{array}{l}4.01 \pm 0.45 \\
(1.61-5.04)\end{array}$ & $\begin{array}{l}2.39 \pm 0.11 \\
(1.79-2.70)\end{array}$ & $\begin{array}{l}3.80 \pm 0.39 \\
(1.61-4.59)\end{array}$ & $\mathrm{P}<0.05$ \\
\hline
\end{tabular}


Glass waste: Mean composition of glass waste was significantly higher in station $2(1.84 \pm 0.18)$ than other stations, with the least value reported in station 1 $(0.08 \pm 0.01)$.

Metal waste: Mean composition of metals waste was significantly higher in station $2(3.03 \pm 0.12)$ than other stations, with the least value reported in station 1 (1.10 \pm 0.08$)$.

Other wastes: Mean composition of other waste was significantly higher in station $2(4.01 \pm 0.45)$ than other stations, with the least value reported in station 1 $(0.19 \pm 0.02)$.

Conclusion: From the results, residents in the study areas in Abraka generate mostly organic and recyclable wastes with most residence tieing these wastes and disposing them on illegal open dumps. It was also observed that an increase in the number of people in a household or the type of job determines the quantity or type of waste generated. In Abraka, no organization is willing to take responsibility for regulating waste management as resources to state and local government are often limited.

\section{REFERENCES}

Ahmed, SA; Ali, M (2004). Partnerships of solid waste management in developing countries: linking theories to realities. Habit. Inter.28(3): $467-479$.

Ahmed, YA; Jimoh, HI; Ifabiyi, IP (2000). Waste Generation and Management. 500pp. Haytec Press and Publishing Co. Ltd, Ibadan, Nigeria.
Batool, SA (2009). Municipal Solid Waste Management in Lahore City District, Pakistan. $J$. Waste Manage. 29:1971-1981.

Delta state government (2007). Map of Delta state. Retrieved June, $2014 . \quad$ From www.delta.state.gov.ng.

Mongtoem, Y; Fujiwara, T; Sethy, S (2014). Attitudes and practices on household solid waste generation, separation and recycling; a case of Phom Penh, Cambodia. Inter. J. Environ. Waste Manage. 15:40-53.

Mongtoem, Y; Fujiwara, T; Sethy, S (2014). Evaluation of household solid waste treatment and recycling method for Phom Penh, Cambodia. $J$. Mat. Cycles. Waste Manage. 6:21-35.

Seo, SA; Aramaki, T; Hwang, Y; Hanaki, K (2004). Environmental Impact of Solid Waste Treatment Methods in Korea. J. Environ. Engineer. 130:8189.

Sharholy, M; Ahmad, K; Mahmood, G; Trivedi, RC (2008). Municipal Solid Waste Management in Indian Cities A Rev. Waste Manage. 28(2):459467.

Zhen-Shan, L; Lei, Y; Xiao-Yan, Q; Yu-mei, S (2009). Municipal solid waste management in Beijing City. J. Waste Manage. 5(2):43-55. 